\title{
Emerging Land Markets in Rural and Urban China: Policies and Practices*
}

\author{
Samuel P.S. Ho and George C.S. Lin
}

\begin{abstract}
This article examines the evolution of China's land system in the past two decades. Since the early 1980s, China has altered its land use arrangements and introduced new regulations to manage land use changes. In the process the administrative allocation of land to users has been transformed into a complex hierarchical system of primary and secondary markets for land use rights. The changes in China's land system were adopted primarily for two reasons: to develop land markets to allocate land more efficiently and to protect agricultural land. An analysis of available data suggests that the development of land markets is still at an early stage, that the conversion of land to non-agricultural use continues but at a slower pace, and that illegal land use is pervasive. The article concludes with an assessment of the new land system and a discussion of some likely future changes.
\end{abstract}

In the past 20 years China's land system, the institutions and laws that define and regulate the relationships between land and its users, has undergone numerous and often significant changes. The process began in the early 1980s with the adoption of the household responsibility system that dramatically altered the relationship between China's farmers and the land they cultivated. Since then numerous other changes have been introduced, including the adoption of the Land Management Law in 1986 (subsequently revised in 1988 and 1998) and the commercialization of urban land use rights in the late 1980s. These changes and a growing concern about China's ability to allocate land efficiently and to reduce the wasteful use of scarce farmland in a period of rapid economic and social change have stimulated a host of new research on China's land policies and land use. Recent research has focused on three related issues: land use, property rights and land management.

Research on land use has focused largely on the decline in cultivated area and has shown that, while much of the decline in farmland was caused by structural changes within agriculture, a significant cause of the loss was the conversion of farmland to non-agricultural use ${ }^{1}$ Research on property rights has focused on such issues as the meaning of state and

* This article is part of a project on rural change in the People's Republic of China at the UBC Centre for Chinese Research and was carried out with the aid of grants from the International Development Research Centre, Ottawa, Canada, the Hong Kong Research Grant Council, and the University of Hong Kong. The authors are grateful to Qu Futian for his support, participants at a workshop in Nanjing in October 2000 who helped clarify many of the issues discussed in this paper, Edgar Wickberg for helpful comments, and Chen Jianglong, Chen Haiqiu and Feng Shuyi for research assistance.

1. See, for example, Vaclav Smil, "China's agricultural land," The China Quarterly, No. 158 (June 1999), pp, 414-429 and Robert Ash and Richard Edmonds, "China's land resources, environment and agricultural production," The China Quarterly, No. 156 (December 1998), pp. 836-879. 
collective ownership, the impact of short-term leases and land readjustments on tenure security, and regional variations in the evolution of rural property rights. ${ }^{2}$ Much of the research on land management was stimulated by the rapid and sometimes uncontrolled land development that has occurred in some of China coastal cities since $1978 .^{3}$

This article falls into the third category, land management. Specifically, it examines how land administration in China has evolved and how land management has been actually practised in the past two decades. Previous studies of land management have focused primarily on urban land. This article takes a broader approach. Since sectors are interrelated, we believe that land management in one sector cannot be separated from that in another. Our focus is on the national level, but regional variations in management practices are noted where appropriate. The research is based partly on a careful examination of China's land management laws and documents issued by the central and selected provincial governments and partly on fieldwork, including interviews with officials of the Land Administration Bureau in Beijing, Shandong, Jiangsu and Guangdong.

The article briefly describes the land system that existed in China under central planning, then discusses how this system has been reformed since 1978, focusing on two major changes: the emergence of land markets and the way the government manages and controls land use. Specifically, it discusses the different types of transactions that are permitted in urban areas (the urban open market), those permitted in rural areas (rural open market), and those not permitted but which occur nevertheless on the black market. Data collected by the Land Administration Bureau is used to gauge the performance of the new land management system in controlling land conversion and to shed light on the characteristics of the newly emerged "land markets." The article concludes with an assessment of the new land system and a discussion of some probable future changes.

\section{The Land System under Central Planning}

How land is managed and regulated in China depends on its location, ownership and use. The most important location distinction is that between rural and urban. ${ }^{4}$ For all practical purposes, private ownership of land ended in China in 1956, and since then the state has owned all land in urban areas, and state and collective ownership of land have co-existed

2. See, for example, Peter Ho, "Who owns China's land? Policies, property rights and deliberate institutional ambiguity," The China Quarterly, No. 166 (June 2001), pp. 394-421 and Roy Prosterman, Tim Hanstad, Brian Schwarzwalder and Li Ping, "Rural land reform in China and the 1998 Land Management Law," RDI Reports on Foreign Aid and Development, No. 98, December 1998.

3. See, for example, Anthony Gar-on Yeh and Fulong Wu, "The new land development process and urban development in Chinese cities," International Journal of Urban and Regional Research, Vol. 20, No. 2 (1996), pp. 330-353 and Tim Hanstad and Li Ping, "Land reform in the People's Republic of China: auctioning rights to wasteland," Loyola of Los Angeles International \& Comparative Law Journal, Vol. 19, No. 3 (1997), pp. 545-583.

4. The 1990 "Interim regulations of the People's Republic of China on the granting and transferring of the right to the use of state owned land in cities and towns" defines "urban" as cities, county towns, designated towns, and industrial and mining areas. 
in rural areas. The 1996 survey of land resources found 53 per cent of China's territory was owned by the state and 46 per cent by collectives. ${ }^{5}$ For purposes of management and regulation, land in China is classified as agricultural land, construction land (land used for non-agricultural purposes) or unused land. ${ }^{6}$ Agricultural land includes cultivated land, yuandi (orchards, vineyards and plantations), forest and pasture. The 1996 land survey reports that rural collectives own nearly 94 per cent of China's cultivated land and yuandi and about 44 per cent of its pasture and forest land. Of the 45 per cent of China's agricultural land that is state owned, nearly 97 per cent is pasture or forest. Unused land is primarily wasteland, mostly state owned and concentrated in the western half of the country. ${ }^{7}$ Since the focus of the article is on the critical relationships between state and collective ownership, rural and urban, and agricultural and non-agricultural land use, the discussion will ignore "unused land." In addition, it will not examine the management and regulation of stateowned rural land since the issues involved are similar to those concerning collectively owned rural land, which will be discussed in depth, and rules and laws that regulate the conversion of agricultural land generally apply to both collectively owned and state-owned land.

Figure 1 presents a simplified schematic diagram of China's land system under central planning. It is simplified because only two sectors are identified: the urban-state sector (urban areas where all land is state owned) and the rural-collective sector (rural areas where land is collectively owned). The rural-state sector (rural areas where land is state owned) is not included. Single-line boxes represent the main players in the land system (those who make decisions about land use and those who use land), double-line boxes represent the different types of land owned by the state and rural collectives, and lines with an arrow indicate processes or transactions through which rights to land are transferred. Because there is very little agricultural land in urban areas, only construction land is explicitly identified in Figure 1.

During the 1960s and the 1970s, China had no separate land administration agency at either the central or provincial level to co-ordinate and supervise land use. The state (as represented by its various agents such as the Ministry of Agriculture, the State Commission for Capital Construction and local governments at or above the county level) and rural

5. Liu Yucheng, Zhongguo tudi ziyuan diaocha shuju ji (A Compilation of Results from the Survey of China's Land Resources)(Beijing: Quan guo tudi ziyuan diaocha bangongshi, 2000 ), p. 34. The ownership status of the remaining $1 \%$, comprising mostly pasture, forest and unused land, was not determined and remains a source of considerable conflict between the state and rural collectives.

6. The Land Management Law of the People's Republic of China (hereafter Land Management Law), adopted in 1986 and revised in 1988 and 1998 (Art. 4) defines "agricultural land" as "land used directly in agricultural production," "construction land" as "land on which buildings or other structure are built, including land used for urban and rural housing and public works, ..., etc.," and "unused land" as "land other than agricultural land and construction land."

7. More than three-quarters of China's unused land is state owned and nearly $80 \%$ of it is found in Xinjiang, Xizang, Qinghai, Gansu and Inner Mangolia (Liu Yucheng, Compilation, pp. 28-29, 40-41 and 64-65). 
Figure 1: China's Land System Under Central Planning

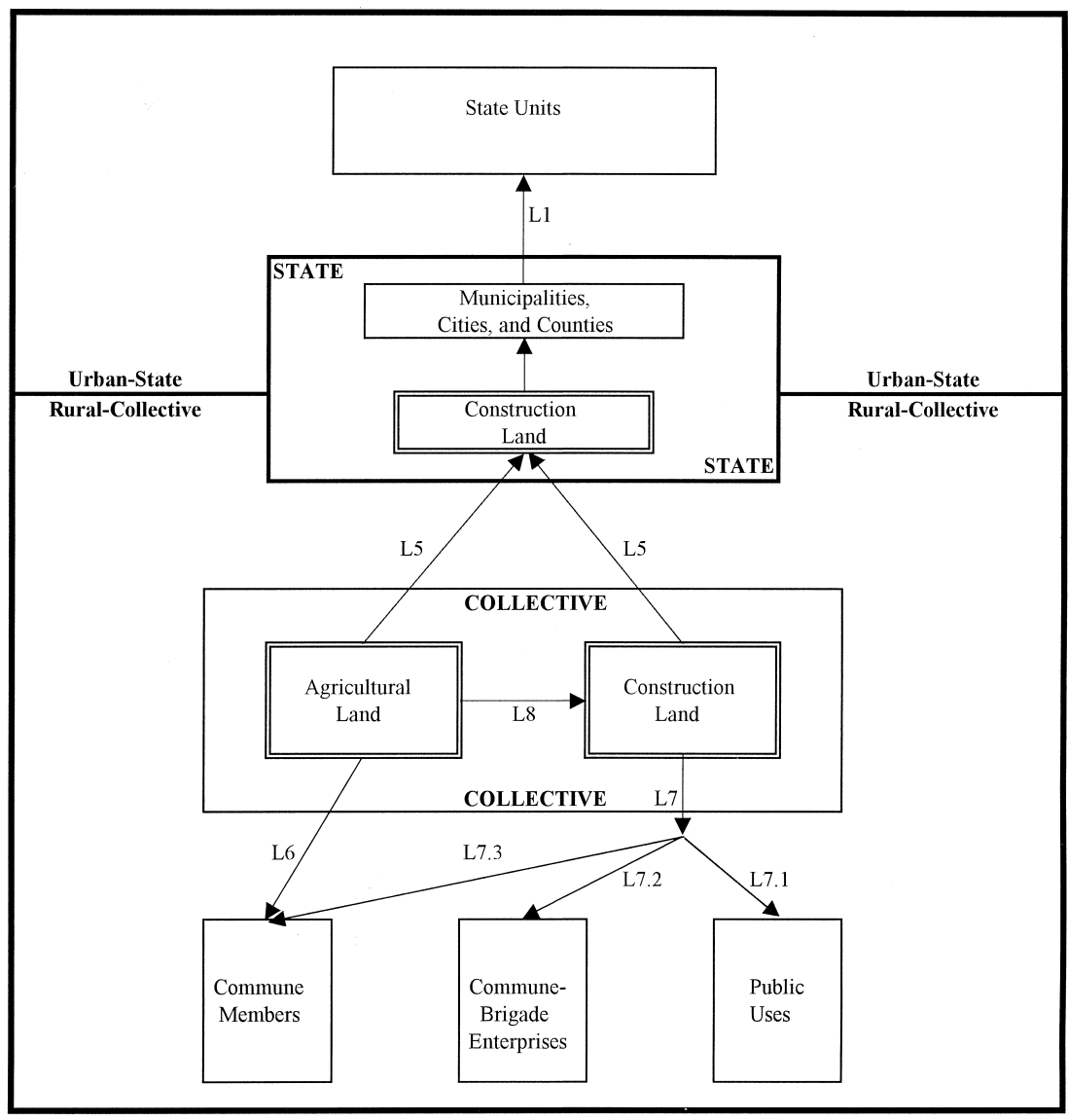

Legend

A decision maker of

land use or a user of land

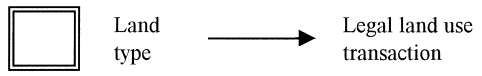

collectives made all land use decisions. In the urban-state sector, local governments at or above the county level (municipalities, cities and counties), acting on decisions of various state agencies, administratively allocated (huabo) land to final users (state and urban collective units), shown in Figure 1 as $\mathrm{L} 1{ }^{8}$ The right to use land was allocated to state units with no time limit and virtually free of charge. Collectively owned agricultural land was worked collectively except for a small portion that rural collectives distributed to their members for use as private plots (L6).

8. Since 1953, state units that need land must apply to the local government for permission even when more senior government units have made the land use decisions. See C. W. Kenneth Keng, "China's land disposition system," Journal of Contemporary China, Vol. 5, No. 13 (1996), pp. 327-28. 
Rural collectives also distributed existing non-agricultural land among their members and collectively owned entities (L7) for use as housing sites (L7.3), enterprise sites (L7.2), and sites for public works and public welfare undertakings (L7.1). Rural collectives made most land allocation decisions at the brigade (administrative village) or production team level, including decisions involving changes in land use such as the conversion of agricultural land to construction land (L8). ${ }^{9}$ Under China's constitution, the state had the right to expropriate collectively owned land if it was in the public interest, and state expropriation was the only way to shift land from use in the rural collective sector to use in the urban state sector. ${ }^{10}$ In other words, for a state unit to gain access to the use of a piece of collectively owned land, the local government, acting on behalf of the state, must first expropriate the land (L5) and then allocate the use rights to the state unit.

The land system that evolved under central planning had several well-known problems. Because land was allocated at prices that did not reflect its opportunity costs, users had little or no incentive to economize. Administrative allocation was also an inefficient management tool since it could not automatically discriminate between the more productive land uses and the less productive, and was slow to respond to economic changes. Another problem was that cities and rural collectives faced serious conflicts of interest as regulators of land use since they were also major land users. For all these reasons the land system lacked an effective mechanism to control the demand for construction land and to prevent the wasteful use of land. In short, judged by either efficiency or sustainability, the land system under central planning was defective.

\section{Reforming the Land System}

Reform measures introduced after 1978 have forced China to modify its land system. A new approach to rural development emerged during 1978-83, and two of the most significant changes introduced were the adoption of the household responsibility system and the promotion of "simultaneous development" of all economic activities. The household responsibility system distributed agricultural land to households and shifted decision-making, including many land use decisions, from the collective to the household. The simultaneous development of rural activities allowed rural residents to engage in all kinds of non-agricultural activities and by so doing created a new demand from individuals and rural enterprises for non-agricultural land. Foreign and overseas Chinese businesses, attracted by China's open policy and urban reforms, demanded not only access to land but also clearer land use regulations and property rights. It became increasingly clear that administrative allocation

9. However, frequently the land conversion decision was made by the commune or by the county. See Liu Xinhua (ed.), Xin tudi guanli fa quanshu (Encyclopedia of New Land Management Laws) (Beijing: Zhongguo wujia chubanshe, 1998), pp. 150 and 170.

10. "The Constitution of the People's Republic of China," adopted 20 September 1954, Art. 13. 
might not be able to handle the massive reallocation of urban land needed to improve urban infrastructures and to move industries from urban centres to the suburbs.

Finally, as reform deepened, the official attitude towards private ownership changed. In 1988 the constitution was amended to give legal status to private enterprises (siying qiye) and to confer on the private sector a "supplementary role" in the economy. Then in the early 1990s, China began to experiment with alternative ownership forms for enterprises in the collective and state sectors. This led eventually to the "grasp the large, release the small (zhuada fangxiao)" policy, under which a large number of collective and state-owned enterprises have been "privatized." In 1999 another constitutional amendment elevated the private sector from its "supplementary role" to an "important integral part" of the economy. To accommodate the legitimacy and the increased importance of the private sector, the land system also had to change.

To help cope with land use problems created by reform, particularly the conversion of cultivated land to non-agricultural use, China enacted the Land Management Law in 1986. The law established the State Land Administration Bureau (Guojia tudi guanli ju) (hereafter Land Bureau), a new nation-wide administrative bureaucracy that reports directly to the State Council, and gave it the responsibility to provide comprehensive management (including the development of land management policies) of all rural and urban land. ${ }^{11}$ Since 1987 the Land Bureau has promoted the development of land markets by separating land use rights from ownership and introduced new rules and tools to regulate the conversion of cultivated land to construction land. To help implement its policies, the Land Bureau has established branches at the provincial, prefecture or prefecture-level city (diji shi), county, and town/township levels.

The new land system shares many of the basic features of the old system. The state is still the sole owner of urban land, and rural residents collectively still own all land in rural areas (except what belongs to the state in accordance with the law). ${ }^{12}$ The state, represented primarily by local governments at or above the country level, and rural collectives continue to play major roles in land allocation and the management of land use. And the state continues to have a monopoly over inter-sector land transfer. What has changed is the emergence of land markets and how government manages and controls land use. In the reformed land system, there are two legal or open land markets, one urban and one rural. Transactions on these open markets include all legal transfer of rights to

11. In 1998 the State Land Administration Bureau changed its name to Guotu ziyuan bu (Ministry of Land and Resources) when it and several other central government agencies were merged. However, this article uses its old name.

12. However ambiguities remain in the law. For example, while the Land Management Law clearly states that urban land is owned by the state, it is silent about who represents the state, an ambiguity that has caused many ownership disputes between government agencies and was not removed until 1998 when the law was revised to declare that the State Council exercises state ownership. For an interesting analysis that argues that Chinese policy makers have introduced deliberately "institutional ambiguity [about ownership]" into the law so as to avoid social conflict, see Ho "Who owns China's land?" pp. 403-409. 
Figure 2: China's Urban Open Land Market

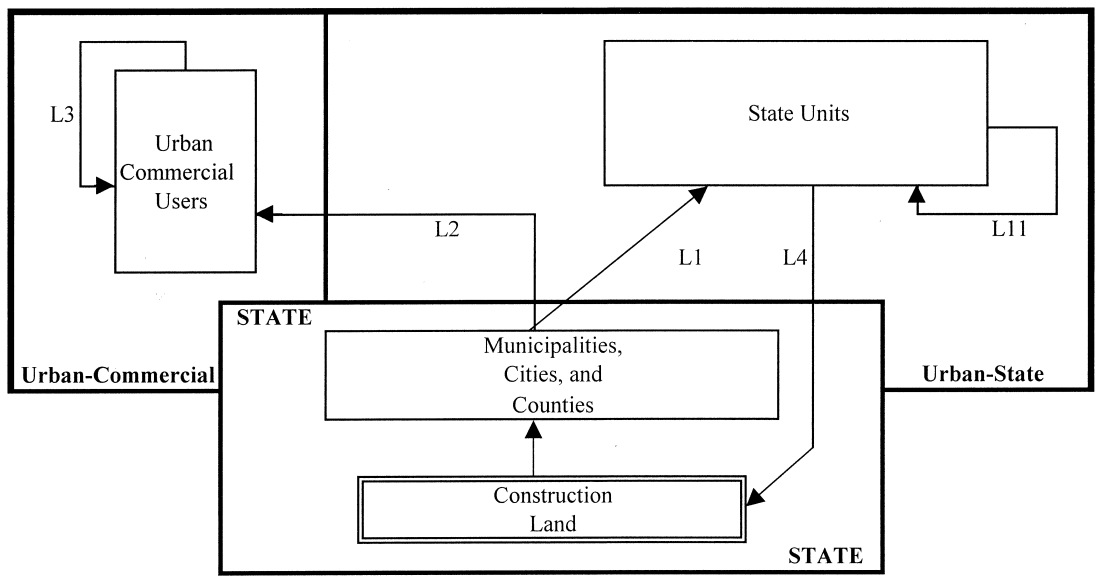

Legend

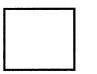

A decision maker of

land use or a user of land

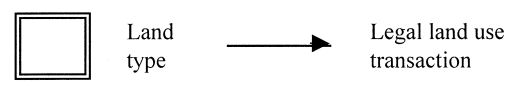

land as well as those whose legality is unclear either because the law is vague or because they are not covered by existing laws. These legally "grey" transactions exist because China's land markets are in their early stages of development and because policy changes usually precede the enactment of laws. Besides the legal markets, there also exists a black market that covers land use and land transactions that are illegal under existing Chinese law. In what follows we first examine the two open land markets and then provide a complete overview of the current land system including the black market.

The urban open land market. To accommodate the separation of land use rights from ownership, the commercialization of land use rights and the growing importance of private activities, the single urban sector depicted in Figure 1 has evolved into two urban sectors: the urban-state sector and the urban-commercial sector (see Figure 2). When China commercialized land use rights in 1988, it introduced a "dual-track" system (a "plan" track and a "market" track) to assign land use rights in urban areas. ${ }^{13}$ Land use rights are assigned in two ways: allocation (huabo) and conveyance (churang). Allocation is used to dispense land use rights to state owned or non-profit users (L1) without time limits and conveyance is used to transfer land use rights to commercial users (L2)

13. The commercialization of land use rights was first tried in Shenzhen on 9 September 1987 and was formally adopted when Article 10 of the Constitution was amended on 12 April 1988 to permit the assignment of the right to use land. 
for a fixed period (40 years for commercial land, 50 years for industrial land and 70 years for residential land). ${ }^{14}$

Together allocation and conveyance constitute the "primary market (yiji shichang)" for land use rights. ${ }^{15}$ State allocation is transacted at an "allocation price" consisting of three main components: the expropriation cost of the land (zhengdi fei, the cost of changing the ownership status of the land from collective to state ownership), various stipulated land fees (tudi guifei) and a government set allocation fee (huabo fei). ${ }^{16}$ State conveyance is transacted at a "conveyance price" consisting also of three major components, of which two are identical to those included in the allocation price (the expropriation cost and the stipulated land fees). The third component is the conveyance fee (churang jin), which is "market determined" in that it is negotiated (xieyi) or determined by public tender (zhaobiao) or auction (paimai). The market determined conveyance fee is usually substantially higher than the allocation fee. In other words, state units are able to obtain land use rights at costs that are much lower than those paid by commercial users and with no time limit.

By paying the higher conveyance fee, commercial users gain the right to participate in the "secondary market (erji shichang)" for land use rights, shown as L3 in Figure 2. ${ }^{17}$ Specifically, holders of land use rights obtained through conveyance may transfer these rights to others (zhuanrang), rent to others the land on which they have use rights (chuzu) or use their land use rights as collateral (diya). Together these transactions are called circulation (liuzhuan). The ability to participate in the secondary market adds significant additional value to land use rights. For one thing, the price for land use rights in the secondary market (zhuanrang jin) may be substantially higher than the conveyance price in the primary market. Furthermore, the ability to mortgage one's land use rights is tremendously important in an economy where the capital market is underdeveloped and where banks are unwilling to lend without collateral.

The right to participate in the secondary market is not available to those who had obtained land use rights through allocation. However, it is possible to move land from state use to commercial use by compensating the state for the difference between the allocation price and the conveyance price. Cities (as agents of the state) can also reacquire land that previously had been allocated to state-owned units (L4) by paying the necessary compensation fees (including a demolition fee, chaiqian fei) and then selling the use rights to the reacquired land to commercial users

14. "Interim regulations of the People's Republic of China on granting and transferring the right to the use of state owned land in cities and towns," Art. 12.

15. While conveyance is the preferred and the most commonly used commercial method to transfer land use rights on the primary market, two other methods that are occasionally used should be noted. The state has rented land to some reformed state enterprises on an annual basis when they are unable to pay the lump sum conveyance price up front, and in exceptional cases, has also permitted the exchange of enterprise shares for the rights to use state land.

16. If the government had invested in basic infrastructure, a fee to cover development cost (kaifa fei) would also be included in the allocation and conveyance prices. Recently "allocation fee" was renamed "compensatory fee for the use of state owned land (guoyou tudi youchang shiyong fei)."

17. Earlier it was noted that enterprises occasionally have rented land from the state. Obviously, such rented land is not permitted to enter the secondary market. 
at the conveyance price (L2). State-owned enterprises that have changed their ownership form, before they can participate in the commercial secondary market for land use rights, are also required to pay the state a conveyance fee for the land use rights they had received previously through allocation. While it is illegal for one state unit to sell its land to another state unit, the exchange of land between state units (huhuan) is permitted if the transaction is registered and the parties involved pay the stipulated fees and the land appreciation tax (tudi zhengzhi shui), if any. ${ }^{18}$ The exchange of land between state units, shown in Figure 2 as L11, does not occur frequently, but is nevertheless a "secondary market" that allows land use rights to circulate within the urban-state sector.

The rural open land market. Although the commercialization of land use rights is less developed in rural areas than in urban areas, it has nevertheless become sufficiently important that the rural open land market now must be represented by two sectors: the rural-collective sector and the rural-commercial sector (see Figure 3). As in Figure 1, the rural-state sector (rural areas where land is state owned) is omitted. The land allocation process in rural areas has undergone many changes.

Since the adoption of the household responsibility system in the early 1980s, rural collectives (usually the village) have "contracted" agricultural land to rural households for agricultural production (L6). ${ }^{19}$ In exchange for the payment of "fees" to the collective, rural households have become the residual claimants on the income generated on the contracted land. Rural households do not have the right to convert the contracted agricultural land to non-agricultural use. While practice varies from region to region, the amount of land contracted to a household in principle is based on its size and composition. As the household size and composition has changed, land distribution has been adjusted. ${ }^{20}$ When the household responsibility system was first introduced, the length of the land use contract was three years. In 1984, to improve tenure security, this policy was changed, and villages were urged to contract land to farmers for 15 or more years. ${ }^{21}$ Then in November 1993, the policy was

18. If the exchanged land is of equal value, no tax is paid. But if the exchanged land is of unequal value, then the party that receives additional cash compensation must pay a land appreciation tax on the cash component.

19. A nation-wide survey found that $68.1 \%$ of the contract was between the village and its member households. See Liu Yanping, Cheng Ye and Wang Jun, "Shichang jingji tizhi xia woguo nongcun jiti tudi chanquan zhidu goujian silu" ("Some ideas for the establishment of a rural collective land property system in our country under a market economy"), Zhongguo tudi kexue (China Land Science), Vol. 12, No. 4 (1998), p. 11.

20. By the late 1990 s, at least $80 \%$ of the villages in China had adjusted land allocation at least once and some five times or more. See Jean C. Oi, "Two decades of rural reform in China: an overview and assessment," The China Quarterly, No. 159 (September 1999), p. 618. Two types of land adjustments have been reported: "big" and "small." When big adjustments are made, all farmland is taken back and then reallocated so households get different plots of land. Under small adjustments, farm households that have added or lost members since the previous adjustment receive or return land to the village, but those who have not will continue to farm the same land. Big land adjustments have frequently been used to facilitate the conversion of agricultural land to construction land.

21. That secure land use rights are essential to agricultural development is widely held among development economists and policy makers, a view supported by evidence from many regions in the developing world. The contractual arrangement initially adopted under the 
Figure 3: China's Rural Open Land Market

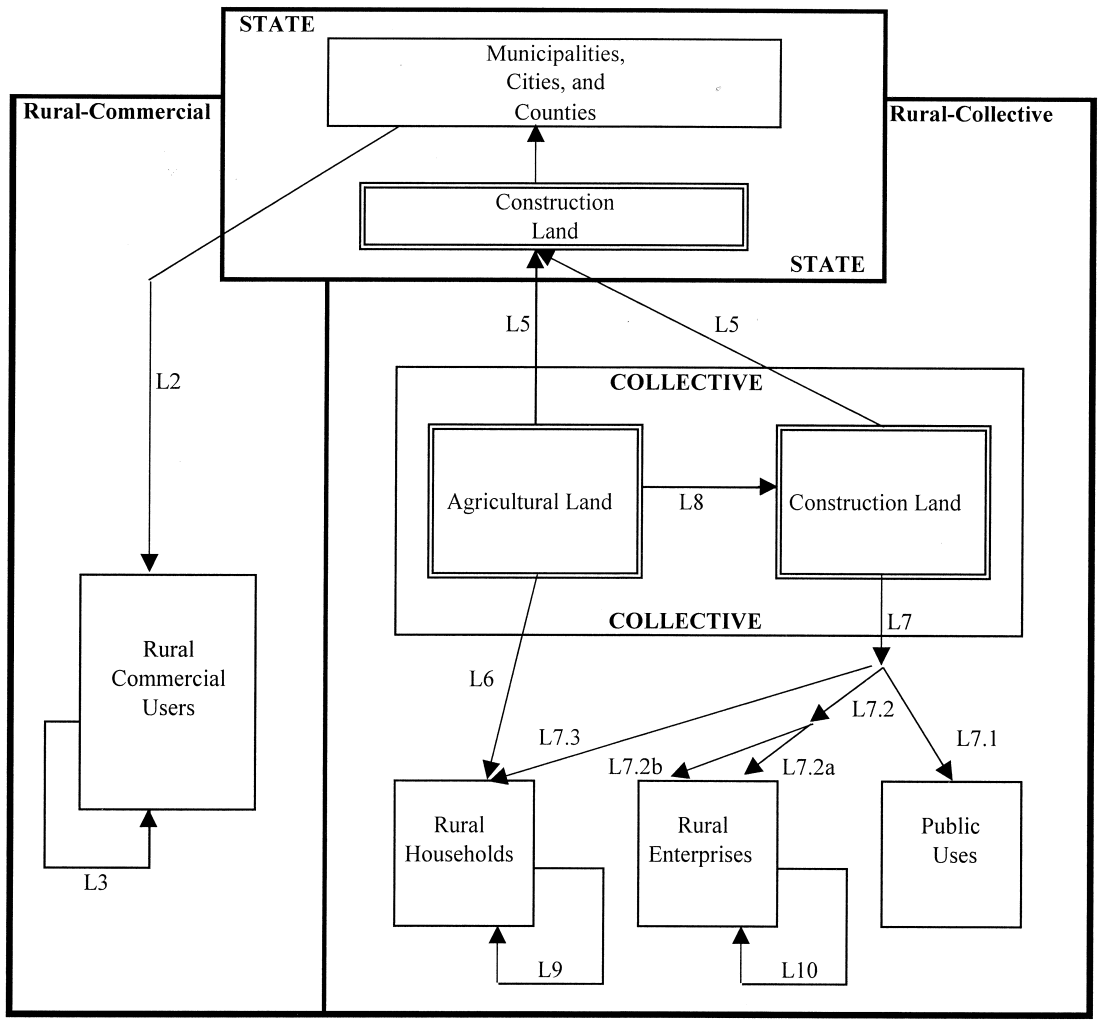

Legend

A decision maker of

land use or a user of land

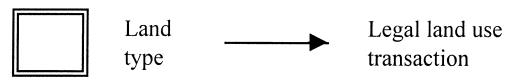

changed again and localities were told that land might be contracted for another 30 years when the original 15-year contract expired. However, surveys have shown that these policies to lengthen land use rights have generally not been widely implemented..$^{22}$ The policy that land should be contracted for 30 years with no adjustments finally became law when the Land Management Law was revised in $1998 .^{23}$

footnote continued

household responsibility system is considered insecure not only because of its short duration but also because of the practice of land adjustments, particularly big adjustments since they result in households getting different plots of land and therefore discourage farmers from making plot-specific land augmenting investment. However farmers also want access to land to accommodate increases in household size. Thus there are tensions between farmers' concern for tenure security and their desire for continued equal entitlement to land.

22. Prosterman et al., "Rural land reform in China," p. 12.

23. Under the 1998 Land Management Law, readjustment is permitted but "must be agreed [to] by at least two-thirds of the members of the villagers' meeting or at least two-thirds of the villagers' representatives" and be approved by both the township and county governments (The 1998 Land Management Law, Art. 14). In other words readjustments can occur but only in rare and isolated cases. 
Shortly after the adoption of the household responsibility system, a "secondary" market for contracted agricultural land developed (L9). Rural households began to exchange contracted plots in order to consolidate their holdings, and when farmers left their villages to work in non-agricultural jobs, some sub-contracted their land to others in the village, usually for a season. ${ }^{24}$ Government policy permitted such exchanges and transfers within the collective but their legal status was unclear until the 1986 Land Management Law declared, "the right to the use of land owned ... by collectives may be lawfully transferred." ${ }^{25}$ By the mid-1980s sub-contractors in some places were mostly people from other regions, and many of them sub-contracted on a regular basis. And in areas where local residents were no longer interested in farming, villages began to contract agricultural land directly to outsiders. The sub-contracting and contracting of land to outsiders were legally grey transactions until 1998 when the Land Management Law was revised to allow explicitly the contracting of agricultural land to non-members of the collective or to another collective unit (if at least two-thirds of the members agree.). ${ }^{26}$ However, the law is still unclear about the types of transfers permitted. Currently, actual practices vary from region to region. For example, the current policy in Jiangsu is to encourage all forms of exchange of contracted agricultural land in the secondary market as long as the transaction does not change the ownership of the land, alter the use of the land as specified in the original contract and extend beyond the term of the original contract. ${ }^{27}$ But until detailed regulations are issued, many activities in the secondary agricultural land market will remain legally "grey" transactions.

Since reform, the rural collective has retained its authority to assign existing rural construction land within the rural collective sector (L7) for use as housing sites for its members (L7.3), enterprise sites (L7.2), and sites for public works and public welfare undertakings (L7.1). However, there are now stricter controls over the use of construction land. ${ }^{28}$ When assigning construction land to users, rural collectives must now comply with the township overall land utilization plan (tudi liyong zongti guihua) and the annual land utilization plan (tudi liyong niandu jihua). ${ }^{29}$ Furthermore village households may now possess only one residential plot, and housing construction must comply with the local size standards. Secondly, the decisions of rural collectives are now subject to approval by

24. However, in some areas, the collective restricted such transfers of use rights and sometimes imposed sanctions on those who migrated and left their land uncultivated or not well cultivated. For an analysis of the trade-offs and competing interests that have brought about these regional variations in rural property rights changes, see Shouying Liu, Michael R. Carter and Yang Yao, "Dimensions and diversity of property rights in rural China: dilemmas on the road to further reform," World Development, Vol. 26, No. 10 (1998), pp. 1789-1806.

25. The Land Management Law, adopted in 1986 and revised in 1988, Art. 2.

26. The 1998 Land Management Law, Art. 15.

27. Interview notes, Jiangsu, 17 October 2000.

28. The information in this paragraph is from the 1998 Land Management Law, Arts. 59, 60,61 and 62 .

29. The overall land utilization plan is a long-term plan (usually 15 years) and consists of two maps (current land use and planned land use) and a set of explanatory notes. The annual 
the County Land Bureau. Thus, the new system places some distance between land users and the regulator of land as they are now from different levels of the state-collective hierarchy.

Ownership reform has brought about a third important change. Since the adoption of the "grasp the large, release the small" policy in 1996, an increasing number of township-village enterprises (TVEs) have changed their ownership form, converting from township or village collective enterprises to shareholding companies, shareholding co-operatives or private companies. Some of the reformed enterprises, because they want to participate in the secondary market for land use rights in the rural-commercial sector (L3), have paid the required conveyance fee to the county for the land previously allocated to them. In other words, they went through the process of having their assigned land "expropriated" by the state (L5) and then buying the right to use that land through conveyance (L2). These procedures, in effect, moved these enterprises from the rural-collective sector to the rural-commercial sector. However, many reformed enterprises have remained in the rural-collective sector but have changed their relationship with the collective to a commercial one (L7.2b), that is they now pay a rent or give shares to the collective for the right to use the land they occupy. ${ }^{30}$ These commercial arrangements have developed in part because most of the reformed TVEs are unable to pay the required lump sum conveyance fee in order to move to the rural-commercial sector and in part because collectives are reluctant to see their construction land converted to state ownership when they receive no part of the conveyance fee (the "profit" from expropriation-conveyance). ${ }^{31}$ Of course, unreformed TVEs continue to receive construction land from rural collectives through allocation (L7.2a).

There is a secondary market for rural construction land that is used occasionally by rural enterprises (L10). Rural enterprises may exchange their land use rights if the transaction is properly registered and the

\footnotetext{
footnote continued

land utilization plan, which gives annual land use targets, is based on and is used to implement the overall land utilization plan. The 1986 Land Management Law required governments at all five levels to develop overall land utilization plans. But during the late 1980s and early 1990s, many regions in China did not have such a plan because they lacked reliable land use statistics or did not have the necessary planning capacity. In the mid-1990s, when China began to develop its second overall land utilization plan (1996-2010), all counties had completed a land survey and planners for the first time had reliable land use statistics. Land use must now comply with this second overall land utilization plan, which has become an important management tool.

30. In the latter case, collectives receive dividends instead of rent. Because the "Sixty Articles" designated the production team as the owner of agricultural land, land rent and dividends paid by enterprises on collective land they use should in theory go to the production team for redistribution. And, indeed, this is the case in regions where the sense of team ownership has remained strong, e.g. Suzhou prefecture in Jiangsu (interview notes, Jiangsu, 2 June 2001). But in many parts of China, the administrative village has used some or all of the land rent and dividends paid by enterprises to cover village expenses, a practice that has caused discontent among some villagers.

31. The central government takes roughly $30 \%$ of the conveyance fee, and the remaining $70 \%$ is divided among local governments (usually only those at or above the county level). None of the conveyance fee is shared with the rural collective.
} 
enterprises pay the stipulated fees and the land appreciation tax (if any). ${ }^{32}$ They may also use their buildings and land use rights as collateral. However, because collectively owned land is of little value to banks, as it cannot be circulated in the commercial secondary market, few banks are willing to accept a rural enterprise's land use rights as collateral. Until this limitation is changed, L10 is likely to remain undeveloped.

Of all land transactions involving collectively owned land, the two that have received the most government attention are the conversion of agricultural land to rural non-agricultural use (L8) and the expropriation of collectively owned land by the state (L5) for use in the urban-state and the commercial sectors. The former transaction involves a change in how land is used, and the latter a change in ownership form (and usually also use). The attention is easy to understand since in the past two decades cities and rural collectives have converted large amounts of rural land, much of it cultivated, to non-agricultural use. Prior to 1978, slow income growth and tight political control kept residential construction in rural areas to a minimum. After 1978, when rural reform brought prosperity and more relaxed control, the pent-up demand for better housing set off a major housing boom in rural areas that diverted an increasing amount of rural land to residential use. Another source of demand for construction land was the rapid development of rural non-agricultural activities that previously were either prohibited or tightly regulated. Finally, urban expansion and the growth of small and medium-sized cities, the result of urban reform, rapid rural non-agricultural development and the open policy, brought about an almost uncontrolled conversion of rural land to built-up areas during the late 1970s and throughout most of the 1980s.

Concerned by the loss of farmland to construction, the government began in the early 1980 s to apply new application, inspection and approval procedures for acquiring construction land; to establish standards and limits on residential building sites; and to urge townships and villages to rationalize land use by developing overall land utilization plans. ${ }^{33}$ Many of these new regulations were incorporated in the 1986 Land Management Law. The tool used in the late 1980s to manage the conversion of rural land was the annual land utilization plan that sets quotas for the use of rural land in construction. ${ }^{34}$ Each year the quotas were set nationally, and then distributed downwards, first divided among provinces, then among prefectures, counties and finally townships. While the annual land utilization plan provided guidelines and set overall limits, actual control was left to a hierarchical system that reviewed and approved requests for the use of agricultural land in construction.

Prior to 1982 , decisions to use agricultural land for construction were made at the commune (now township) level. In 1982, to put some

32. Interview notes, Jiangsu, 16 October 2000.

33. See Xiangzhen qiye zhengce fagui xuanbian (Selected Laws and Regulations Concerning Township-Village Enterprises), pp. 52-57.

34. The first annual land utilization plan was formulated by the Land Bureau in 1987, and in 1988 the annual land utilization plan was integrated into the annual economic development plan. See Chinese Academy of Social Sciences, Institute of Finance and Trade Economics and Institute of Public Administration USA, Urban Land Use and Management in China (Beijing: Jingji kexue chubanshe, 1992), pp. 211-13. 
distance between the user of land and the regulator, such decisions were transferred to a higher level of government. From 1982 to 1986, the conversion of agricultural land to non-agricultural use had to be approved by the Agricultural Bureau at the county level. Under the 1986 Land Management Law, state construction projects using up to $3 \mathrm{mu}$ of farmland (or up to $10 \mathrm{mu}$ of non-agricultural land) required approval by the Land Bureau at the county level; those using between 3 and $10 \mathrm{mu}$ of farmland (or between 10 and $20 \mathrm{mu}$ of non-agricultural land) required approval at the prefecture level; and those using between 10 and 1,000 $m u$ of farmland (or between 20 and 2,000 mu of non-agricultural land) required approval at the provincial level. ${ }^{35}$ State construction projects that used more than 1,000 $\mathrm{mu}$ of farmland (or 2,000 $\mathrm{mu}$ of non-agricultural land) required approval by the State Council. Rural residents and individual enterprises (geti hu or geti qiye) needing land for construction must now submit a land use application to the village committee or the village (or township) collective economic entity for examination and the county government for approval. ${ }^{36}$ Surprisingly, the rules issued in 1991 to implement the Land Management Law were silent about land use by TVEs.

The annual quotas and the hierarchical review and approval process proved ineffective. In many counties and cities, profits from land expropriation and conveyance became important, and local governments developed a strong revenue motive to expropriate collective land for conveyance to commercial users. Because profits from land conveyance were shared among governments at different levels, senior governments could not be relied upon to check the excessive land conversion at lower levels. Provincial and county governments also lacked the resources to monitor land use activities in their jurisdiction and were dependent on lower-level officials to ensure compliance and to keep the conversion of land to construction use within the quotas. It was also relatively easy for lower-level officials to find ways around the hierarchical approval process. For example, local governments could easily expand their approval authority by dividing large projects into smaller ones and multi-year projects into "independent" annual projects.

The failure of this system moved the government to consider alternative ways to protect agricultural land. In November 1991 it called for the establishment of "protected primary farmland regions (jiben nongtian baohu qu)." 37 This was followed by the promulgation of the "Regulations for the protection of primary farmland" in August 1994 that prohibited the removal of primary farmland from cultivation. ${ }^{38}$ Finally, the govern-

35. However, there are regional variations in the standards (Jiangsu interview notes, 1987 and interview notes, Guangdong, 19 June 2001).

36. However if the land is part of an existing residential site or an empty space within the village, the township government has the authority to approve the land use application. See State Council, "Rules for the implementation of the law of the People's Republic of China on land management," promulgated 4 January 1991.

37. See Liu Xinhua, Encyclopedia, p. 495.

38. See "Jiben nongtian baohu tiaoli" ("Regulations for the protection of primary farmland"), State Council Order, No. 162, 18 August 1994. 
ment rewrote the Land Management Law in 1998, establishing a new comprehensive land management system to protect farmland. The revised law requires each province to designate at least 80 per cent of its cultivated land as primary farmland, and significantly tightened the rules governing the use of agricultural land for construction. ${ }^{39}$ Furthermore the law requires provincial governments to "adopt measures to ensure that the total amount of cultivated land within its administration region is not reduced," and if reduced to take responsibility for the reclamation of an equal amount of land within its administration region or in a different location. ${ }^{40}$ In effect, the new system replaced the hierarchical approval system with strict limits on the amount of agricultural land that may be converted to construction land each year and a "no reduction" rule on total cultivated land.

At present, the system requires government approval at the provincial level or higher for all expropriation of agricultural land and most conversions of land from agricultural to construction use. Specifically, the expropriation of any primary farmland, cultivated land other than primary farmland in excess of 35 hectares, and other land in excess of 70 hectares requires the approval of the State Council. ${ }^{41}$ The expropriation of land in all other cases requires government approval at the provincial level and must be reported to the State Council. In the rural-collective sector, construction by residents and enterprises must comply with the overall land utilization plan, that is, construction must be on land specifically designated for construction. Under the current plan, there is a mandatory total cap on the amount of farmland that can be converted to construction land during 1996-2010, which is divided into annual caps for implementation. Each year, in accordance with the cap set by that year's plan, the province approves in "batches" the amount of agricultural land that may be converted to construction land (if the land is primary farmland, State Council approval is required). Because prefectures may submit land use applications to the provincial government for approval only a limited number of times a year, the application process is now significantly more time consuming. Local governments at the township and county levels first submit land applications to their prefecture government. Only after a sufficient number has been received are the applications forwarded by the prefecture to the province for approval. ${ }^{42}$ To streamline the process, a few provinces have decentralized it. For example, in Jiangsu, the province has

39. The 1998 Land Management Law, Art. 34. However it is still possible for localities to manipulate the rules. For example, we were told that some localities have classified poor land as "primary farmland" and good farmland in areas with development potentials as "poor" land (interview notes, Shandong, 24 May 2001).

40. The 1998 Land Management Law, Art. 33. When cultivated land is converted to construction land, the user of the land takes responsibility for reclaiming land equivalent in size and quality to the occupied land. The user usually does this by paying a land reclamation fee, which "must be used exclusively to reclaim new land for cultivation" (The 1998 Land Management Law, Art. 31).

41. The information in this paragraph is from the 1998 Land Management Law, Ch. V.

42. For example, in Shandong, each batch of applications submitted by prefectures for provincial approval must involved at least $200 \mathrm{mu}$ of land (interview notes, Shandong, $24 \mathrm{May}$ 2001). 
distributed its annual cap to prefectures and downwards to counties. ${ }^{43}$ Thus, in Jiangsu, counties may approve individual projects that require agricultural land as long as the use is in compliance with the township overall land utilization plan, the total conversion is within the authorized cap for the locality and all stipulated fees have been paid.

The current land system: open and black markets. Because illegal land use is pervasive in China, legal transactions constitute only a part, albeit a majority, of all land use transactions. Land is often occupied without approval or with approval obtained by fraud. Local governments often exceed their authority when approving land use applications or approved projects that use land in ways that do not comply with the overall land utilization plan. And, in some cases, government units with no authority to approve land use have approved the occupation of land. Rural collective land has also been transferred illegally, often with the co-operation of rural collectives, for use by commercial users. Together the legal and illegal transactions (or the open and black markets) constitute China's current land system, and they are shown in one diagram in Figure 4.

Illegal land transactions are depicted in Figure 4 as dashed lines with arrow. I1 represents the leakage of collectively owned and state owned land to illegal uses, of which six are identified. I2 is the illegal use of collectively owned land by rural commercial users. ${ }^{44} \mathrm{~A}$ frequently cited example is the inclusion of land in the sale of a TVE (the price of the enterprise includes both land and non-land assets). This apparently occurred - inadvertently or by design - fairly frequently when the policy of "releasing the small" was first implemented. Since county governments were under pressure to implement ownership reform they were reluctant to break up sales agreements once they were signed. I3 is the illegal use of collectively owned land by rural households. This usually involves peasants illegally occupying collective land when building or expanding their houses (for example claiming they are building on existing construction land when in fact they are using cultivated land, occupying building plots larger than the approved limit, and building houses without going through the application, approval and registration processes). Another example of I3 is the mutual exchange of contracted agricultural land among peasants without proper registration (to avoid paying the stipulated fees). I4 is the illegal use of collectively owned land by rural enterprises. An example is the exchange of construction land between two rural enterprises without proper registration (to avoid paying the stipulated fees and the land appreciation tax).

43. Interview notes, Jiangsu, 17 October 2000. We were told that Zhejiang has also decentralized the approval process in a manner similar to that in Jiangsu.

44. The information in this and the following paragraphs is from Yang Chongguan and Wu Cifang, Zhongguo tudi shiyong zhidu gaige shinian (China's Land Use System, Ten Years of Reform) (Beijing: Zhongguo dadi chubanshe, 1996), pp. 179-82, Wang Yunhe (ed.), Wuxi shi tudi zhi (History of Land in Wuxi City) (Nanjing: Jiangsu renmin chubanshe, 1998), pp. 268-70, Wang Zhongyi (ed.), Jiangyin shi tudi zhi (History of Land in Jiangyin City) (Nanjing: Jiangsu renmin chubanshe, 1998), pp. 283-86, and interview notes, Jiangsu, 17 October 2000. 
Figure 4: China's Current Land System

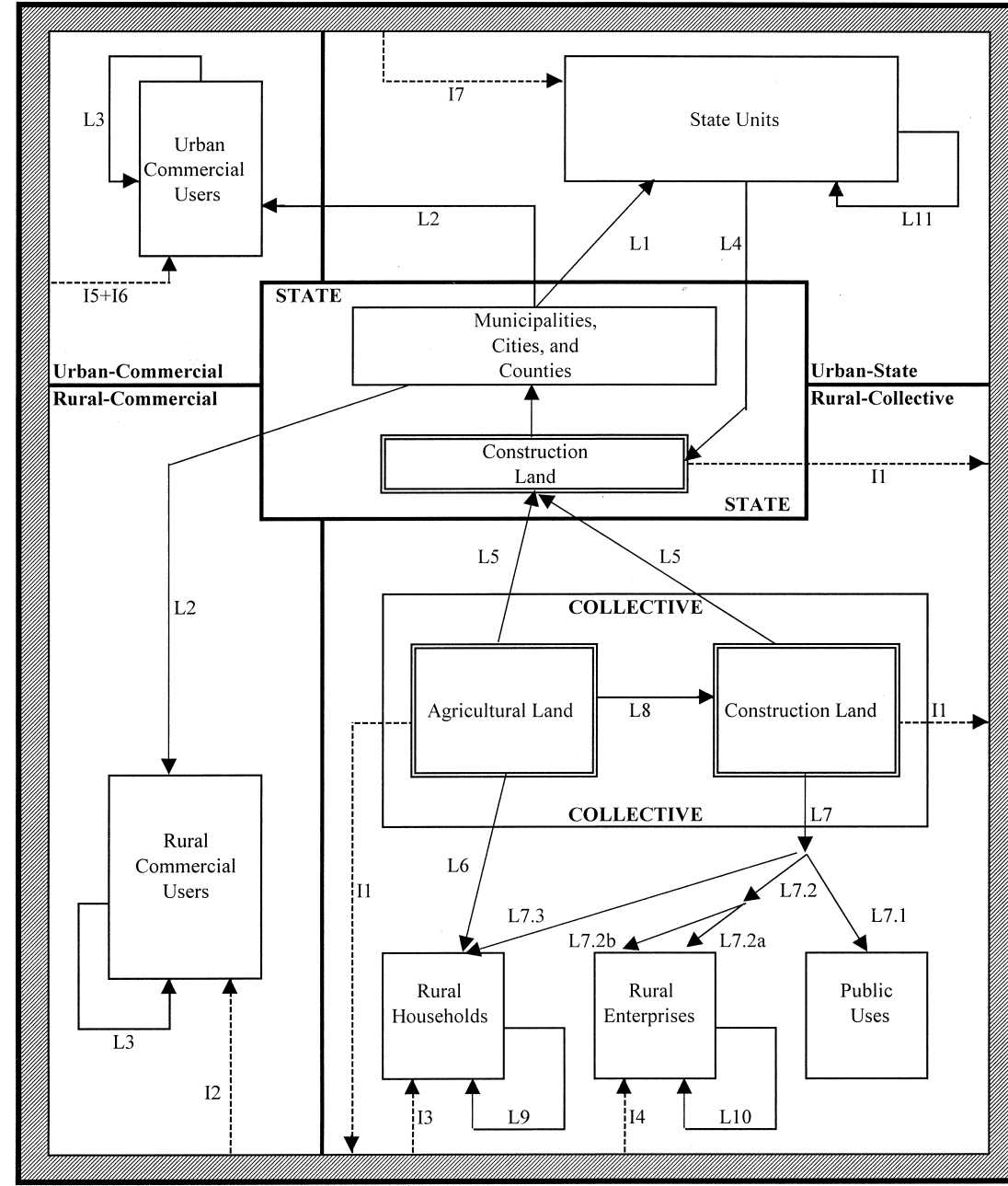

Legend

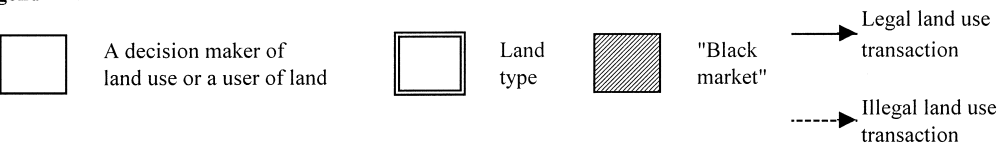

I5 is the illegal use of collectively owned land by urban commercial users. This happens when peasants or rural collectives, to capture the appreciated value of their land, lease or transfer to urban commercial users use rights to collectively owned land without going through the necessary expropriation process. An example of I5 is a rural collective exchanging land for shares in an urban company (yidi rugu) without first applying for and receiving approval from the county land bureau. I6 is the illegal use of state construction land by urban commercial users. An example is a reformed state enterprise exchanging its allocated land in the 
secondary market (L3) without first paying a conveyance fee to the state. I7 is the illegal use of state land by state units. An example is the mutual exchange of construction land by state units without proper registration (to avoid paying the stipulated fees and the land appreciation tax).

\section{Rural Land Conversion and Emerging Land Markets: Some Evidence}

The changes in China's land system discussed above were introduced primarily for two reasons: to develop land markets so land can be allocated more efficiently and to protect agricultural land. The evidence suggests that rural land conversion has slowed but not to the level desired by the central government, that land market development is still at an early stage, and that an active black market continues to exist.

A slower rate of rural land conversion. Table 1 presents the recorded conversion of cultivated land to construction land between 1993 and $1996 .^{45}$ In 1993 China converted about 134,000 hectares of cultivated land to non-agricultural use. Compared to the 1980s, this represents a significant decline. During 1985-88, China had lost on average 208,333 hectares of cultivated land per year to construction, roughly 1.5 times the loss in $1993 .{ }^{46}$ The main reason for this decline was a huge drop in the use of cultivated land for rural housing, from an annual average of roughly 68,700 hectares during $1985-88$ to 10,768 hectares in $1993 .^{47}$ However, the taking of farmland by cities and towns, railways and highways, industrial and mining sites, and TVEs continued to remain at relatively high levels. These categories together accounted for roughly two-thirds of the total cultivated land lost to construction in 1993.

It would appear that by the early 1990s the loss of cultivated land to rural housing was under control but the loss of farmland to state and rural collective construction still remained at a high level. During the mid1990s, the loss of cultivated land to construction declined, falling from 134,480 hectares in 1993 to 97,020 hectares in 1996, led by a sharp decline in the taking of cultivated land by cities and towns and by TVEs. Cultivated land lost to urban expansion in 1996 was half that in 1993, and that lost to TVEs was one-fifth. However there was no perceptible downward trend in the taking of cultivated land for rail and highway construction.

45. No data on land conversion has been published since 1996. There was a government freeze on the conversion of farmland to construction land in 1997-98 so presumably little cultivated land was lost to construction during these years.

46. Calculated from statistics reported in "Guojia tudi guanli ju guanyu jiaqiang nongcun zhaijidi guanli gongzuo de qingshi" ("State Land Administration Bureau notice on the strengthening of the management of rural residential land"), 15 December 1989.

47. The government reported that about one-third of the loss in cultivated land to construction during 1985-88 was due to rural housing. One third of 208,333 hectares is roughly 68,700 hectares. The figure for the loss of cultivated land to rural housing in 1993 is from Zhongguo tudi nianjian 1994-1995(China Land Yearbook, 1994-1995) (Beijing: Renmin chubanshe, 1995), p. 149. 
Table 1: Conversion of Cultivated Land to Construction Land, 1993-1996

\begin{tabular}{lrrrr}
\hline & 1993 & 1994 & 1995 & 1996 \\
\hline Total (hectares) & 134,480 & 133,140 & 105,446 & 97,020 \\
Cities and towns & 41,388 & 36,494 & 27,507 & 20,383 \\
Rail and highway & 16,974 & 22,368 & 16,865 & 16,399 \\
Industrial and mining sites* & 17,815 & 16,858 & $* *$ & $* *$ \\
Township-village enterprises & 12,663 & 9,711 & 5,296 & 2,664 \\
Rural road & 5,521 & 7,451 & 1,543 & 2,072 \\
Irrigation & 11,818 & 11,199 & 8,047 & 5,633 \\
Rural housing & 10,768 & 11,726 & 10,637 & 10,174 \\
Other construction & 17,533 & 17,333 & 35,551 & 39,695 \\
Percentage of total & & & & \\
Cities and towns & $30.8 \%$ & $27.4 \%$ & $26.1 \%$ & $21.0 \%$ \\
Rail and highway & $12.6 \%$ & $16.8 \%$ & $16.0 \%$ & $16.9 \%$ \\
Industrial and mining sites* & $13.2 \%$ & $12.7 \%$ & $* *$ & $* *$ \\
Township-village enterprises & $9.4 \%$ & $7.3 \%$ & $5.0 \%$ & $2.7 \%$ \\
Rural road & $4.1 \%$ & $5.6 \%$ & $1.5 \%$ & $2.1 \%$ \\
Irrigation & $8.8 \%$ & $8.4 \%$ & $7.6 \%$ & $5.8 \%$ \\
Rural housing & $8.0 \%$ & $8.8 \%$ & $10.1 \%$ & $10.5 \%$ \\
Other construction & $13.0 \%$ & $13.0 \%$ & $33.7 \%$ & $40.9 \%$ \\
\hline
\end{tabular}

Notes:

* Includes development zones (kaifa qu).

** Included in "other construction."

Total percentage may not equal 100.0 due to rounding.

Sources:

Calculated from data in Zhongguo tudi nianjian (China Land Yearbook), 1994-95 (pp. 130-31) and 148-49), 1996 (pp. 214-15), and 1997 (pp. 199-201).

The data presented so far measure only the legal conversion of farmland to non-agricultural use. Anecdotal evidence suggests that illegal use of land is widespread. ${ }^{48}$ By its nature, illegal activity is difficult to quantify. But some evidence exists. ${ }^{49}$ Between 1993 and 1996, 941,453 cases of illegal land use involving 133,065 hectares of land (including 77,512 hectares of cultivated land) were uncovered. In other words, the uncovered illegally occupied cultivated land during 1993-96 encompassed an area that was about 18 per cent of the cultivated land that was legally approved for occupation in the same period. This suggests a high level of illegal activity. Fifty-three per cent of the violators were peasants, probably caught using land illegally when building or expanding their houses. However illegal activities by peasants were responsible for only 6.6 per cent of the illegally occupied cultivated land. The big violators were rural collectives (particularly villages) and state entities. During 1993-96, state-owned units and villages accounted for over half the

48. See, for example, Yang Chongguan and Wu Cifang, Zhongguo tudi shiyong zhidu gaige shinian (China's Land Use System, Ten Years of Reform), pp. 179-182 and 186-190.

49. The following statistics were calculated from data in China Land Yearbook, 1994-95 (pp. 118, 122, 140 and 144), 1996 (pp. 199 and 201), and 1997 (pp. 173 and 175). 
illegally used cultivated land. In view of the level of illegal activities uncovered by the government, one suspects the annual conversion of agricultural land to non-agricultural use may be significantly higher than the data in Table 1 suggest.

China's land markets, small but growing. Of the open land markets identified in Figure 4, reliable information exists only for two, the primary and secondary markets for the rights to use state-owned urban land (see Table 2). For comparison purposes, Table 2 also presents the available data on illegal land use. Reflecting the growth in the number of private enterprises, reformed state and collective enterprises, and joint ventures, the number of conveyances has increased steadily during the 1990 s, from 42,076 in 1993 to 130,417 in $1998 .{ }^{50}$ But the data also show that during the 1990s allocation was still the main method used to distribute rights to use urban land, accounting for nearly three-quarters of the transactions and about 70 per cent of the land distributed in the primary market. Of the land use rights distributed by conveyance in the five years for which data are available, 89 per cent were "negotiated" and only 11 per cent transacted through "open bidding" by public tender or auction. In other words, the vast majority of land conveyance was done in the least open or transparent way.

Most of the land distributed by conveyance is found in areas where reform has moved forward aggressively. In 1996, the coastal provinces (Liaoning, Beijing, Tianjin, Hebei, Shandong, Jiangsu, Shanghai, Zhejiang, Fujian, Guangdong and Hainan) accounted for two-thirds of the land distributed by conveyance and nearly 72 per cent of the receipts generated from land conveyance. ${ }^{51}$ Guangdong and Hainan alone accounted for about 27 per cent of the land distributed by conveyance and over 20 per cent of the receipts generated from land conveyance. Arguably the relative importance of conveyance in the primary market is one of the best indicators of how well reform is progressing.

During the 1990s, activities in the secondary market for rights to use urban land increased significantly, both in terms of the number of transactions and the amount of land transacted. Between 1993 and 1998, the number of transactions in the secondary market rose from 132,077 to 449,428 and the amount of land involved increased from 11,271 to nearly 1.1 million hectares. The number of transactions involving the transfer of land use rights more than tripled between 1993 and 1998, with the largest increase occurring in the late 1990s. But the most dramatic increase was in the use of land use rights as collateral. Between 1993 and 1998, the number of times that a land use right was used as collateral increased from 1,592 to 104,476 and the amount of land mortgaged rose from

50. However, the amount of land distributed by conveyance has not increased significantly, mainly because the average size of land distributed by conveyance in 1993 was unusually large, about 3.5 times the average size of the other years, probably a reflection of the early activities of land developers.

51. Calculated from data in China Land Yearbook, 1997, p. 183. 


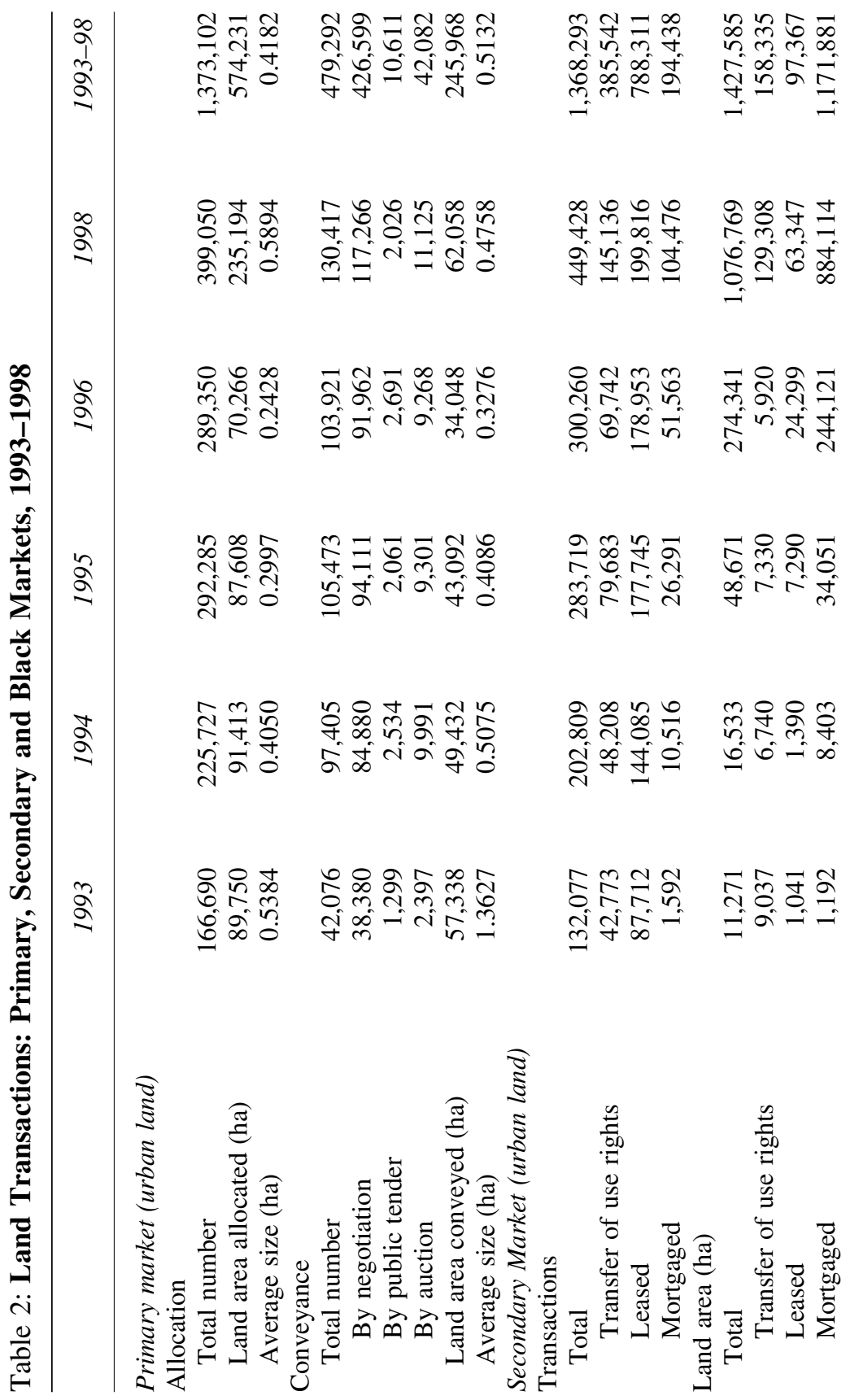




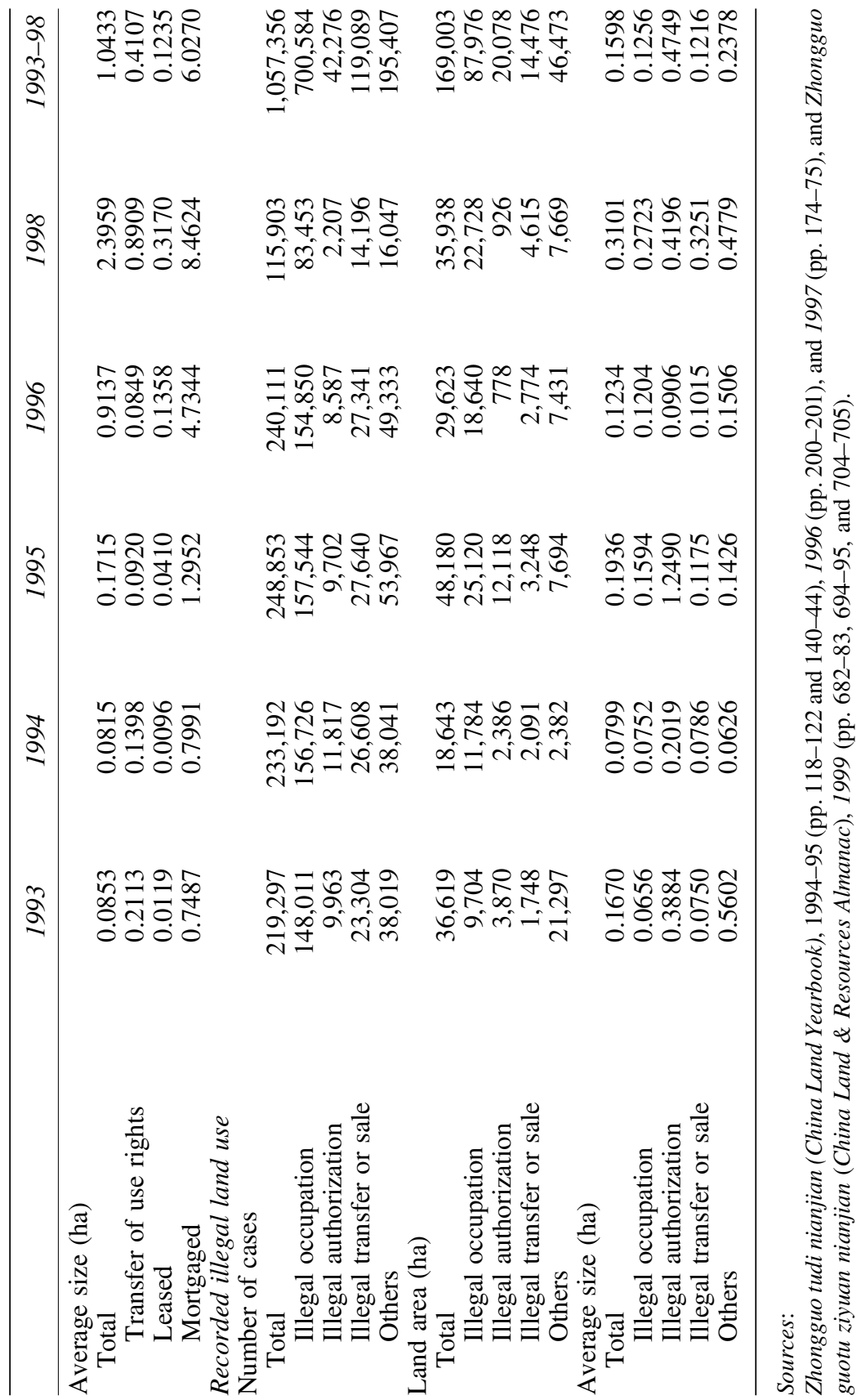


around 1,000 to over 884,000 hectares. As with the primary market, the secondary market for rights to use urban land has developed more rapidly in the coastal provinces, particularly in Guangdong and Zhejiang. In 1996 the coastal provinces accounted for 64 per cent of the total transaction value on the secondary market.

For comparison, Table 2 also presents statistics of illegal land use, and they suggest an active black market. Between 1993 and 1996, the number of recorded incidents of illegal land use was at least twice the number of land conveyances completed, although usually smaller in terms of the area involved (the exception being 1995). In 1998, the number of cases of illegal land use declined dramatically, falling to below 116,000 from 220,000-240,000 in 1993-96. However, the total area involved did not decline, suggesting that this was caused by a fall in the number of "small" violators. The vast majority of illegal land use in 1998 (72 per cent by the number of cases and 63 per cent by the size of land illegally used) was "illegal occupation (feifa zhandi or shanzi zhanyong)," followed by the "sale or illegal transfer of land use rights (maimai he feifai zhuanrang)."

Unlike the urban open market, which is more developed in the coastal provinces, illegal land activities appear to be as robust in the interior as on the coast. For example, of the illegal land use cases uncovered in 1996, 23 per cent were found in the coastal provinces and 77 per cent in the interior. When measured in terms of area, 40 per cent of the land under illegal use (or illegally transferred) uncovered in 1996 was in the coastal provinces and 60 per cent in the interior. ${ }^{52}$ The five provinces with the highest incidence of cases of illegal land use in 1996 were (in descending order by the number of cases uncovered) Shaanxi, Zhejiang, Hunan, Henan and Sichuan. The high incidences in the interior provinces probably reflect the fact that a large proportion of the illegal land activities involved peasants and rural land.

Explaining illegal land activities. Illegal land use on the scale found in China in the 1990s requires explanation. One possible reason is ambiguous property rights, particularly in rural areas. Surveys have found that many in the countryside do not know who owns the land. ${ }^{53}$ For decades, collectives have made land use decisions in rural areas and not surprisingly believe they have the right to dispose land when in fact they do not. Since most land use regulations were formally adopted recently, people are also unfamiliar with them. Together, these factors may explain some of the illegal land use cases, particularly those involving peasants. But they cannot explain the persistency of illegal activity or the illegal behaviour of state and collective units.

The primary reason for widespread illegal land use in China is financial. Tax evasion is the motive for the relatively minor illegal transactions identified in Figure 4 (I3, I4 and I7), that is, the mutual exchange of land without proper registration to avoid the payment of fees

52. Calculated from data in ibid. p. 185.

53. Prosterman et al., "Rural land reform in China," p. 17. 
and the land appreciation tax. The desire to capture some of the profits from land conversion is the motive for the more serious illegal transactions identified in Figure 4 (I2, I5 and I6), that is, the illegal transfer of land use rights from the rural-collective or the urban-state sector to the commercial sector. The latter motive is strong because the potential gains are substantial.

Recall that land use rights obtained through conveyance may be circulated in the commercial secondary market. A state unit who had received its land use rights through allocation may legally participate in the commercial secondary market only if it pays the state a conveyance fee. However, this fee would significantly reduce the net gains from participating in the secondary market, thus creating a strong motive for the illegal transfer of land use rights from the urban-state sector to the urban-commercial sector. The incentive to transfer land from the rural collective sector to the commercial sector without going through the expropriation-conveyance process is also extremely strong. When the state expropriates collective land, it pays the collective and its members an expropriation fee, consisting of three components: compensation for the land, resettlement allowance for the displaced peasants and compensation for young (unharvested) crops ${ }^{54}$ Of these, the first two are most important, and standards for both are set by the central government. ${ }^{55}$ When the government sells the rights to the use of land it has expropriated, it charges a price that covers the expropriation fee, various stipulated fees and the conveyance fee. In effect, the conveyance fee is the profit from land expropriation and conveyance. The stipulated fees are retained by local governments at the prefecture and county (xian or xianji shi) levels, and the conveyance fee is divided between the different levels of government, but none of it is shared with the original land owner. ${ }^{56}$ Given the substantial profit from land conversion, rural collectives and their members have strong incentives to engage in illegal land activities in order to capture a share of this profit.

\section{Summary and Concluding Comments}

In the past two decades China has altered its land system, moving from allocating land use rights administratively to a hierarchical system of primary and secondary land use markets. There are two segmented

54. When there are significant past investments in irrigation, collectives also collect an irrigation compensation fee.

55. The standards from 1986 to 1998 can be found in the Land Management Law, adopted in 1986 and revised in 1988, Arts. 27 and 28, and those after 1 January 1999 can be found in the 1998 Land Management Law, Art. 47. But the law is unclear as to how the compensation should be distributed between the collective and the displaced users, and actual practice varies from region to region.

56. Roughly $30 \%$ of the conveyance fee goes to the central government and $70 \%$ to local governments. See People's Republic of China, Ministry of Finance, "Guoyou tudi shiyong quan youchang churang shouru guanli zhanxing shishi banfa" ("Provisional measures on the administration of income generated from the compensated conveyance of rights to use state owned land"), 26 September 1989, Arts. 4 and 5 and the 1998 Land Management Law, Art. 55 . 
primary markets, one used by the state to allocate urban land and the other by rural collectives to allocate collectively owned land, and both are dual-track markets. ${ }^{57}$ The state continues to allocate urban land administratively to state units at low prices and without time limits, but new economic players now must bid or negotiate for the right to use urban land for fixed periods. Rural collectives allocate most of their land administratively. However, since the mid-1990s a commercial track has developed where reformed TVEs and new rural enterprises rent or negotiate for the right to use collectively owned land. The new land system permits use rights obtained on the primary market to circulate in segmented secondary markets. Four such markets have developed: use rights to state land obtained through conveyance are permitted to circulate in the secondary market in the commercial sector; use rights to state land obtained through allocation may circulate among state users within the urban-state sector; use rights to contracted agricultural land may circulate as long as the land is used for agriculture purposes; and finally, use rights to collectively owned rural construction land may circulate within the rural collective sector.

The development of land markets and the higher conveyance and transfer prices paid by commercial land users have helped promote the more efficient use of land. However, efficiency gains have been limited by the continued importance of administrative allocation and the lack of transparency in land conveyance. In 1998, the most recent year for which data are available, urban land allocated administratively was nearly four times that assigned through conveyance. And of the land assigned through conveyance, nearly 90 per cent was by negotiation, the method that is least transparent, least competitive and most easily manipulated. Negotiations behind closed doors have created opportunities for manipulation and corruption.

Since the mid-1980s the land system has protected agricultural land by regulating land expropriation and the conversion of agricultural land to non-agricultural use. Prior to 1998, the control was a hierarchical review system that required senior governments to examine and approve land expropriation and conversion decisions made at lower levels. But local governments found ways to manipulate and compromise the process. Enforcement was also uneven and weak since the government had to rely on local officials at the township level and below to monitor land use and ensure compliance, but these local officials were also members of a local bureaucracy that had a strong interest in getting construction projects approved. With the revision of the Land Management Law in 1998, the government replaced the hierarchical approval system with strict rules that maintain the status quo, that is, keep total cultivated area at the current level and protect the best-cultivated land from conversion. In

57. It should be noted that there is also a primary market for unused land. In the past, unused land was contracted to rural residents to develop; but increasingly in recent years market allocation has been used. For example, in some parts of China the right to use state or collectively owned wasteland has been auctioned to farmers for periods ranging between 50 and 100 years. 
effect, these rules have centralized decision-making involving land conversion.

In the past, without clear property rights, peasants were unable to resist effectively the compulsory taking of land by the collective. The 1998 Land Management Law, which requires written 30-year land use contracts, if strictly enforced, should significantly improve the security of land tenure in rural China. This in turn should enable peasants to protect their interests better and, by so doing, slow down the conversion of agricultural land to non-agricultural use. However, clearer land use rights are meaningless if they cannot be enforced. It is difficult and costly for individuals to fight the collective or the state in court. The development of a cheap and effective land dispute resolution mechanism will do much to protect agricultural land and the interests of peasants.

Two further observations are worth making. First, the existence of a dual-track primary market and the inability to move land out of the collective sector except through state expropriation encourage illegal land transactions and create opportunities for corruption. Indeed, it is doubtful if illegal land use could have persisted at such high levels year after year without widespread corruption. The second observation concerns equity. The current system of state expropriation has transferred huge amounts of wealth from rural collectives (and their members) to the state. This is a source of tension and bitter resentment in the countryside. Complaints and resistance to land expropriation have forced the government to raise its compensation periodically. But these adjustments have come only after long lags, and the compensation remains well below market value. What makes this transfer of wealth difficult to defend is that it is taking wealth from the poorer (sometimes the poorest) members of society. One possible solution is to move towards a system where approved public projects would acquire land through state expropriation but approved commercial projects would acquire land directly from the collective through negotiation, thus allowing the collective and its members to capture the bulk of the economic gains from land conversion. ${ }^{58}$

How is China's land system likely to change in the future? In the short term, since many if not most state-owned enterprises could not afford to pay the conveyance fee, administrative allocation will continue to be the primary method used to allocate land. In the long term, if reform deepens and more enterprises change their ownership form, administrative allocation will decline in importance. The central government, concerned about corruption and the low prices negotiated for land use rights, may also pressure local governments to rely more heavily on auction to allocate land. ${ }^{59}$ If these changes occur, the urban dual-track primary market will gradually move towards a single-track market. Another likely change is

58. In either case, once sold, the land would be state owned. To implement this change would probably require a constitutional amendment, since China's constitution forbids the sale or transfer of land in ways other than state expropriation.

59. The Ministry of Land and Resources recently announced that after 1 July 2002 the conveyance of rights to use state-owned land for investment purposes would be done either by public auction or by open tender. See Far Eastern Economic Review, 27 June 2002, pp. 28-31. 
the development of a robust secondary market for contracted agricultural land (L9). However this will come about only if the government guarantees secure land tenure by strictly enforcing the 1998 Land Management Law and continues to develop clear rules and procedures concerning the transfer of rural land use rights.

In the foreseeable future, the current land system in rural China is unlikely to change significantly. There is widespread support among farmers for the arrangement of long-term land leases giving them the right to transfer use rights to others when they no longer wish to work their land. A mid-1999 survey of 17 provinces showed that nearly 70 per cent of the surveyed farmers supported the current practice of contracting agricultural land to farm households for 30 years with no readjustment. ${ }^{60}$ The government and rural collectives are also unlikely to want the privatization of rural land since it would further reduce their influence over the use and management of rural land. Finally, the public and collective ownership of land is the last remaining element of socialism still intact, and, for ideological reasons, the government will not want to abandon it.

There is also not the same pressure to privatize land as there was to reform the ownership of state and collective enterprises. The urgency to reform these enterprises was caused in part by the fact that many of them were operating at a loss and had become a serious financial burden for the government. Furthermore, with the legitimization of the private sector, asset stripping had become widespread and capital was leaking at an alarming rate from state and collective enterprises to private hands. Another pressure for reform was the perceived need to change ownership in order to increase efficiency. But conditions are different for land. State and collective ownership does not impose a financial burden on the government. In fact, land conveyance has become an important source of revenue. Asset stripping is also not a problem. Unlike capital, land is immobile and therefore more easily monitored. The recent implementation of a land registration system, one that requires the verification and registration of land ownership and use rights, will also help to control illegal land transactions. ${ }^{61}$ As for the economic argument that, if cultivators were also owners, agricultural investment and thus agricultural productivity would increase, the expected increase can also be achieved without private ownership if tenure is secure, something the 1998 Land Management Law already guarantees. 20.

60. Prosterman et al., "Implementation of 30-year land use rights for farmers," pp. 14 and

61. Since 1987, land ownership by collectives had to be registered (The Land Management Law, adopted in 1986 and revised in 1988, Art. 9). More recently China has required the verification and registration of use rights to rural non-agricultural construction land and use rights to state land (1998 Land Management Law, Art. 11, 12, and 13). 